\title{
BUDAYA KOMUNIKASI BLATER DI DESA TAMBUKO KECAMATAN GULUK-GULUK KABUPATEN SUMENEP MADURA
}

\author{
Saiful Rizal \\ Universitas Islam Negeri Sunan Ampel Surabaya \\ rizal@gmail.com
}

\begin{tabular}{l}
\hline \hline Article Info \\
\hline Article history: \\
Received 14 February 2018 \\
Accepted 16 March 2018 \\
Published 10 April 2018 \\
\hline
\end{tabular}

Keyword:

Budaya komunikasi, blater, Madura
Abstract

Penelitian ini mengkaji tentang bagaimana budaya komunikasi blater yang ada di desa tambuko kecamatan guluk-guluk kabupaten sumenep. Tujuan penelitian ini adalah mengungkap bagaimana bentuk-bentuk komnikasi yang dilakukan oleh blater dalam lingkungan sosial masyarakat Desa Tambuko Kecamatan Guluk-Guluk Kabupaten Sumenep Madura. Metode penelitian ini adalah deskriptif.

Hasil penelitian menunjukkan bahwa: (1) Bentuk komunikasi blater yang yang dilakukan secara simbolik lebih mudah lakukan serta diterima oleh masyarakat desa tambuko, seperti mengikuti adat-istiadat yang memang harus di lakukan, dan tidak melakukan tindakan kriminal di lingkungan desa. Blater itu sendiri dapat menunjukkan eksistensinya sebagai seorang blater melalui komunikasi yang bersifat simbolik, dan hal itu menjadi budaya komunikasi tersendiri bagi blater yang ada di Desa Tambuko. (2) Seorang blater memiliki nilai-nilai tersendiri di mata masyarakat karena tindakan yang mereka tunjukkan. Apabila seorang blater dapat memberikan keamanan bagi warga desanya maka dia akan mendapatkan nilai tersendiri dari tindakannya itu.

Masyarakat akan menilai bahwa blater tersebut betul-betul kuat dan punya pengaruh yang besar dalam dunia kriminal, dan patut untuk dihormati. Blater dalam proses komunikasi secara langsung (verbal) tidak terlalu sering dilakukan. Komunikasi secara verbal dilakukan hanya sekedarnya saja, dan lebih suka komunikasi secara langsung apabila membutuhkan sesuatu atau menghadapi masalah serius yang memang harus diselesaikan dengan jalan pembicaran. 


\section{Pendahuluan}

Komunikasi yang ada pada suku Madura di Indonesia kadang memakai cara-cara berkomunikasi secara alami dan cenderung mistis konvensional, jauh dari iptek tetapi sama-sama efektif hasilnya dan multi aspek menurut mereka. Karapan sapi merupakan media komunikasi masyarakat Madura, untuk menginformasikan saat musim tanam ketika musim hujan mulai turun, saat dimana media lain seperti, $t v$, radio, dan media cetak masih jarang. Saat ini media komunikasi karapan sapi tersebut telah berubah berkembang mengarah pada aspek olahraga dan perkembangan pariwisata bersinergi dengan media informasi lainnya, dan meninggalkan aspek utamanya sebagai media komunikasi alami pertanian. Masyarakat lebih tertarik dengan mempertontonkan sapinya di lomba-lomba dan event 2 pariwisata. $^{1}$

Dari sudut pandang sosial, blater dapat muncul dari strata dan kelompok sosial manapun di dalam masyarakat Madura. Apakah itu di dalam lingkungan dengan latar belakang sosial keagamaan yang ketat (baca: santri), atau lingkungan sosial blater. Tak jarang ditemukan pula, seseorang yang sebelumnya pernah menjadi santri di pondok pesantren dalam perjalanan hidupnya berubah menjadi seorang blater. Blater yang memiliki latar belakang santri, umumnya pandai mengaji dan membaca kitab kuning. Bagi masyarakat Madura sendiri bukanlah

${ }^{1}$ Hub De Jonge, Madura Dalam Empat Zaman: Pedagang, Perkembangan Ekonomi, Dan Islam,(Jakarta: Pt Gramedia, 1989), hal. 40-41 sesuatu yang aneh bila seorang blater pandai mengaji dan membaca kitab kuning karena dalam tradisi masyarakat Madura, pendidikan agama diajarkan secara kuat melalui langgar (musolla), surau, masjid dan lembaga pesantren yang bertebaran di hampir setiap kampung dan desa. Konteks ini pula yang membuat blater dengan latar belakang santri memiliki jaringan kultural dan tradisi menghormati sosok kiai.

Historisitas atau fenomena sejarah keblateran dalam banyak hal seringkali merujuk pada sosok jagoan sebagai orang kuat di masyarakat pedesaan. Tak heran bila konstruksi tentang keblateran sangat terkait pula dengan konstruksi jagoanisme di dalam masyarakat. Blater adalah sosok orang kuat di Madura, baik secara fisik maupun magis dan biasanya dikenal memiliki ilmu kebal, pencak silat atau ilmu bela diri yang hampir bagi sebagian masyarakat mereka dianggap sebagai kelompok pengaman disisi lain atau bahkan bisa disebut sebagai kelompok pengacau pada sisi lain. ${ }^{2}$

Seorang jago/blater dapat dengan mudah mengumpulkan pengikut, anak buah dengan jumlah yang cukup besar. Meskipun besaran jumlah pengikutnya sangat tergantung atas kedigdayaan ilmu (kekerasan) yang dikuasainya. Sosok jago atau blater yang sudah malang melintang di dunia kekerasan, dan namanya sudah sangat tersohor karena ilmu kesaktianya akan menambah kharisma dan kekuatannya untuk mempengaruhi

${ }^{2}$ Tri Sukitman dan Suluh Mardika, Kekuasaan Patrimonial Politik Desa; Analisis Relasi Patron-KlienPadaPemilihan KepalaDesaAeng Tong-Tong SaronggiSumenep, (jurnal Pelopor Pendidikan, Vol 7 No 2, juni 2015) hal. 100 
banyak orang. Kondisi ini mengantarkan sosok jagoan selalu memiliki peran signifikan di tengah masyarakat. Sejak di era prakolonial organisasi jago menjadi satu-satunya alat penguasa.

Blater yang rentan terhadap kekuatan aparatur hukum, seperti kepolisian, seringkali mereka menggunakan demokrasi sebagai legitimasi aktivitas ekonomi-politik mereka yang sarat kriminalitas dan kekerasan. Jagoan yang dikenal sebagai blater ini tumbuh dan berkembang di masa sekarang sudah tidak lagi menjaga nilai-nilai kerakyatan. Padahal, blater di sejumlah daerah memiliki asal-usul populis karena kekuatan idealismenya menjaga kehidupan rakyat dari berbagai praktek dominasi dan kesewenangwenangan penguasa. Di Madura, sejarah Blatèr berawal dari kepentingan resistensi rakyat terhadap kekuasaan.

Kekerasan yang telah mereka lakukan pada masa itu ditujukan untuk gerakan mempertahankan nilai kemanusiaan dari berbagai bentuk. ${ }^{3}$ Bagi setiap orang baik itu blater ataupun bukan, dalam proses sosial mereka tetap memerlukan terhadap keberadaan orang lain di sekitar mereka. Untuk dapat saling berhubungan dalam lingkungan masyarakat maka harus memulai sebuah proses komunikasi, baik itu secara langsung (verbal) ataupun tidak langsung (non verbal). Fungsi komunikasi dalam kehidupan sosial adalah mengisyaratkan bahwa komunikasi itu penting untuk membangun konsep diri, aktualisasi diri,

\footnotetext{
${ }^{3}$ Ardhie Raditya, Politik Keamanan Jagoan Madura, (jurnal studipemerintahan Vol2 no1 februari 2011).
}

untuk kelangsungan hidup, untuk memperoleh kebahagiaan, terhindar dari tekanan dan ketegangan, antara lain lewat komunikasi yang bersifat menghibur. Melalui komunikasi dapat bekerja sama. ${ }^{4}$ Orang yang tidak pernah berkomunikasi dengan manusia, bisa dipastikan akan tersesat, karena ia tidak berkesempatan menata dirinya dalam suatu lingkungan sosial. Komunikasilah yang memungkinkan individu membangun suatu kerangka rujukan dan menggunakannya sebagai panduan untuk menafsirkan situasi apapun yang ia hadapi. Komunikasi pula yang memungkinkannya mempelajari dan menerapkan strategi-strategi adaptatif untuk mengatasi situasi-situasi problematik yang ia masuki.

Dari keterangan di atas dapat diketahui bahwa sosok seorang blater di lingkungan masyarakat Madura adalah orang yang memiliki kekuatan bela diri bahkan magis yang dekat dengan hal-hal yang berbau kriminalitas. Penelitian ini dilakukan untuk mengetahui bagaimana proses komunikasi blater yang mempunyai latar belakang yang berbeda dengan masyarakat pada umumnya.

Dengan adanya penelitian tentang blater yang ada di desa Tambuko ini, peneliti berharap masyarakat yang ada di desa tersebut ataupun dari luar desa bisa saling memahami dan tidak terjadi kesalahpahaman dalam proses berkomunikasi. Karena dalam kehidupan sehari-hari harus bisa membaca dan mengerti terhadap simbol-simbol ketika

\footnotetext{
${ }^{4}$ Deddy Mulyana, Ilmu Komunikasi: Suatu Pengantar,(Bandung:PTRemaja Rosdakarya, 2008), hal. 5
} 
melakukan interaksi, supaya tidak terjadi miskomunikasi.

\section{Kajian Pustaka}

\section{Budaya dan Komunikasi}

Budaya seperti juga komunikasi adalah istilah yang sudah akrab bagi kebanyakan orang. Sebagian dari akibat keakraban ini, istilah budaya digunakan dengan cara yang berbeda-beda. penggunaan yang paling umun dari istilah budaya adalah sebagai persamaan kata dari negri atau bangsa. Jika berkelana melintas, beberapa masyarakat yang menggunakan bahasa bukan inggris, atau mendapati seorang perempuan yang mengenakan cincin di wajahnya, dapat dikatakan bahwa mereka berasal dari budaya berbeda, yang artinya dalam kasus ini, bahwa mereka berasal dari negri yang berbeda.

Budaya adalah suatu konsep yang membangkitkan minat. Secara fomal budaya didefinisikan sebagai tatanan pengetahuan, pengalaman, kepercayaan, nilai, sikap, makna, hirarki, agama, waktu, peranan, hubungan ruang, konsep alam semesta, obyek-obyek materi dan milik yang diperoleh sekelompok besar orang dari generasi ke generasi melalui usaha individu dan kelompok. Budaya menempatkan diri pada pola-pola bahasa dan dalam bentuk-bentuk kegiatan dan perilaku yang berfungsi sebagai modelmodel dari tindakan- tindakan penyesuaian diri dan gaya komunikasi yang memungkinkan orang- orang tinggal dalam suatu masyarakat di suatu lingkungan geografis tertentu pada tingkat

\footnotetext{
${ }^{5}$ Brant D. Ruben, Lea P. Stewart, Komunikasi Dan Perilaku Manusia. (Jakarta: Rajawali Pers. 2013). Hal.358
}

perkembangan teknis tertentu dan pada suatu saat tertentu.

Mereka yang mempelajari tingkah laku manusia memiliki definisi budaya yang lebih tepat. Pengertian budaya tidak menunjuk kepada sesuatu yang dimiliki atau tidak dimiliki oleh orang, juga bukan sesuatu yang terpikir sebagai negatif atau positif. Budaya bukanlah suatu apapun di antara obyek yang dapat di sentuh, dapat diperiksa secara fisik, atau diletakkan dalam sebuah map. Melainkan ia adalah sebuah gagasan, atau sebuah konsep, seperti di kemukakan oleh E. B. Taylor tahun 1871 dengan "yaitu keseluruhan kompleks yang meliputi pengetahuan, kepercayaan, seni, moral, hukum, adat, dan kemampuan lain apapun, dan kebiasaan yang dipelajari dan diperoleh oleh anggotaanggota dari sebuah masyarakat. ${ }^{5}$

Dalam disiplin ilmu antropologi budaya, kebudayaan dan budaya itu artinya sama saja. Menganalisis konsep kebudayaan perlu dilakukan dengan pendekatan dimensi wujud dan isi dari wujud kebudayaan Menurut dimensi wujudnya, kebudayaan mempunyai 3 wujud, yaitu; ${ }^{6}$

Pertama, Kompleks gagasan, konsep, dan pikiran manusia: wujud ini disebut sistem budaya, sifatnya abstrak, tidak dapat dilihat, dan berpusat pada kepala-kepala manusia yang menganutnya. Disebutkan bahwa sistem budaya karena gagasan dan pikiran tersebut tidak merupakan kepingan- kepingan yang terlepas, melainkan saling berkaitan berdasarkan asas-asas yang erat

\footnotetext{
${ }^{6}$ Munandar Sulaeman, Ilmu Budaya Dasar. (Bandung: PT Refika Aditama. 1998). Hal. 12-13
} 
hubungannya, sehingga menjadi sistem gagasan dan pikiran yang relatif mantap dan kontinyu.

Kedua, Kompleks aktifitas, berupa aktifitas manusia yang saling berinteraksi, bersifat kongkret, dapat diamati dan diobservasi. Wujud ini sering disebut sistem sosial. Sistem sosial ini tidak dapat melepaskan diri dari sistem budaya. Apa pun bentuknya, pola-pola aktifitas tersebut ditentukan atau ditata aleh gagasangagasan, dan pikiran-pikiran yang ada didalam kepala manusia. Karena saling berinteraksi antara manusia, maka pola aktifitas dapat pula menimbulkan gagasan, konsep, dan pikiran baru serta tidak mustahil dapat diterima dan mendapat tempat dalam sistem budaya dari manusia yang berinteraksi tesebut.

Ketiga, Wujud sebagai benda: aktivitas manusia yang saling berinteraksi tidak lepas dari berbagai penggunaan peralatan sebagai hasil karya manusia untuk mencapai tujuannya. Aktivitas karya manusia tersebut menghasilkan benda untuk berbagai kebutuhan hidupnya. Kebudayaan dalam bentuk fisik yang kongkret biasa juga disebut kebudayaan fisik, mulai dari benda yang diam sampai pada benda yang bergerak.

Dari penjelasan di atas dapat disimpulkan bahwa komunikasi adalah salah satu wujud kebudayaan. Sebab, komunikasi hanya bisa terwujud setelah sebelumnya ada suatu gagasan yang akan dikeluarkan oleh pikiran individu. Jika komunikasi itu dilakukan dalam suatu komunitas, maka menjadi sebuah kelompok aktivitas dan pada akhirnya komunikasi yang dilakukan tersebut tak jarang membuahkan suatu bentuk fisik, misalnya hasil karya seperti sebuah bangunan. Bukanlah bangunan didirikan karena ada konsep, gagasan kemudian didiskusikan (dengan keluarga, pekerja atau arsitek) dan berdirilah sebuah rumah. Maka komunikasi nyata menjadi sebuah wujud dari kebudayaan. Dengan kata lain komunikasi bisa disebut sebagai proses budaya yang ada dalam masyarakat.

Sedangkan komunikasi menurut Deddy mulyana mengkategorikan definisidefinisi tentang komunikasi kedalam 3 konseptual yaitu; ${ }^{7}$

Pertama, Komunikasi sebagai tindakan satu arah. Suatu pemahaman komunikasi sebagai penyampaian pesan searah dari seseorang (atau lembaga) kepada seseorang (sekelompok orang) lainnya, baik secara langsung (tatap muka) ataupun melalui media, seperti surat (selebaran), surat kabar, majalah, radio, atau televisi. Pemahaman komunikasi sebagai proses searah sebenarnya kurang sesuai bila diterapkan pada komunikasi tatap muka, namun tidak terlalu keliru bila diterapkan pada komunikasi publik (pidato) yang tidak melibatkan tanya jawab. Pemahaman komunikasi dalam konsep ini, sebagai definisi berorientasisumber.

Definisi seperti ini mengisyaratkan komunikasi semua kegiatan yang secara sengaja dilakukan seseorang untuk

\footnotetext{
${ }^{7}$ Deddy Mulyana, Ilmu Komunikasi: Suatu Pengantar,(Bandung:PT Remaja Rosdakarya, 2008), hal. 61-69
} 
menyampaikan rangsangan untuk membangkitkan respon orang lain. Dalam konteks ini, komunikasi dianggap suatu tindakan yang disengajauntuk menyampaikan pesan demi memenuhi kebutuhan komunikator, seperti menjelaskan sesuatu kepada orang lain atau membujuk untuk melakukan sesuatu.

Kedua, Komunikasi sebagai interaksi. Pandangan ini menyetarakan komunikasi dengan suatu proses sebabakibat atau aksi-reaksi, yang arahnya bergantian. Seseorang menyampaikan pesan, baik verbal atau non verbal, seorang penerima bereaksi dengan memberi jawaban verbal atau non verbal, kemudian orang pertama bereaksi lagi setelah menerima respon atau umpan balik dari orang kedua, dan begitu seterusnya.

Ketiga, Komunikasi sebagai transaksi. Pandangan ini menyatakan bahwa komunikasi adalah proses yang dinamis yang secara sinambungan mengubah phak-pihak yang berkomunikasi. Berdasrkan pandangan ini, maka orang-orang yang berkomunikasi dianggap sebagai komunikator yang secara aktif mengirimkan dan menafsirkan pesan. Setiap saat mereka bertukar pesan verbal dan atau pesan non verbal.

Proses yang sama muncul dalam kelompok maupun organisasi, meski jumlah orang yang terlibat lebih besar. Saat jaringan komunikasi muncul dan berubah, pola dan kenyataan yang dibagi pun berkembang. Dalam setiap kejadian ini, kata-kata khusus atau frasa-frasa tertentu, pendekatan kepemimpinan, norma perilaku, atau kesepakatan berpakaian, muncul sebagai hasil dari komunikasi dan adaptasi mutualistik di antara para anggota.

Masyarakat adalah sistem sosial yang lebih besar dan lebih kompleks, yang juga didalamnya berlangsung dinamika komunikasi yang sama. Simbol-simbol dari sebuah masyarakat adalah simbol budaya yang paling bisa dilihat. Simbol adalah dasar budaya setiap masyarakat. Bahasa lisan dan tertulis adalah unsur budaya yang paling dasar, namun, bersamanya ada pula simbol-simbol lain yang juga melayani peran yang sama. Benda-benda tertentu, tempat, orang, gagasan, dokumen, lagu, peristiwa bersejarah, monument, figure pahlawan, gaya arsitek, dan bahkan dongeng rakyak boleh jadi penting bagi sebuah budaya.

Di dalam masyarakat, seperti di dalam sistem sosial lainnya, komunikasi adalah sarana melalui mana individuindividu menciptakan, berbagi dan melanggengkan budaya. Pola komunikasi verbal dan nonverbal yang sama, orientasi keagamaan, politik, gender, perkawanan, membesarkan anak, suku, dan sisi kehidupan sosial lainnya adalah juga menjadi bagian dari budaya di setiap masyarakat

Budaya adalah hasil tambahan dari kegiatan-kegiatan komunikasi yang berlangsung di dalam hubungan, kelompok, organisasi, dan masyarakat. Tentunya, jika tidak karena kapasitas bahasa simbolik manusia, kita tidak akan bisa mengembangkan sebuah budaya bersama. Tanpa komunikasi beserta teknologinya, menjadi tidak mungkin untuk menyampaikan unsur-unsur budaya dari satu tempat ke tempat lain, atau dari 
satu generasi ke generasi berikutnya. Pada waktu bersamaan, pilihan, pola, dan perilaku komunikasi perseorangan berkembang saat beradaptasi kepada tuntutan budaya dan peluang yang kita jumpai di sepanjang perjalanan hidup.

Sejauh bisa nyatakan secara akurat bahwa budaya didefinisikan, dibentuk, ditranmisikan, dan dipelajari melalui komunikasi, sejauh itu pulalah dapat dikatakan secara akurat mengenai hal sebaliknya. Hasilnya, kemudian, adalah saling memengaruhi secara resiprokal, atau pendefinisian secara timbal balik, antara budaya dan komunikasi manusia. Melalui komunikasi akan terbentuk sebuah budaya; dan, pada gilirannya, budaya membentuk pola-pola komunikasi.

Gagasan tentang budaya dan hubungannya dengan komunikasi dapat lebih diperjelas melalui pembahasan karakteristik umum budaya berikut ini: (1) budaya itu kompleks dan bersegi banyak, (2) budaya tidak terlihat, (3) budaya bersifat subjektif, dan (4) budaya mengalami perubahan setiap waktu. ${ }^{8}$

Kompleksitas budaya adalah sesuatu yang paling tampak dan paling potensial dalam bermasalah dalam komunikasi. Di sini, perbedaan bahasa sering melibatkan isu-isu mendasar seperti kebiasaan sosial, kehidupan keluarga, pakaian, kebiasaan makan, struktur kelas, orientasi politik, agama, adat-istiadat, filosofi ekonomi, kepercayaan, dan sistem nilai.

Unsur-unsur budaya tertentu tersebut tidak berada dalam isolasi, tapi, ia saling memengaruhi dengan cara yang halus.

\footnotetext{
${ }^{8}$ Brant D. Ruben, Lea P. Stewart, Komunikasi Dan Perilaku Manusia. (Jakarta: Rajawali Pers. 2013). Hal.362-371
}

Sebagai contoh, nilai dari budaya suatu masyarakat mempunyai dampak kepada ekonomi dan sebaliknya; serta sekaligus memengaruhi dan dipengaruhi oleh kebiasaan masyarakat, agama, dan kehidupan keluarga. Jika memeriksa pola komunikasi verbal dan non-verbal dari budaya manapun, akan terlihat ada pola yang sama pada kompleksitas dan asosiasinya. Bentuk salam, gerak isyarat, tema dan bentuk percakapan, baju, kebiasaan bahasa, praktik berpacaran, kontak mata yang dipilih, penggunaan ruang, orientasi waktu, peran gender, orientasi pada yang lebih tua, dan sikap tehadap kerja semuanya memengaruhi dan pada gilirannya dipengaruhi oleh ragam dimensi budaya.

Meski budaya itu unik dalam beberapa hal, masih dimungkinkan untuk mengidentifikasi pola-pola umum kesamaan dan perbedaannya. Dalam hal orientasi pada praktik komunikasi, budaya dapat dijelaskan dalam tiga cabang tema: konteks tinggi dan konteks rendah, orientasi individu dan kolektif, dan perspektif waktu monokronik dan polikronik.

Ahli komunikasi dan kebudayaan Edward Hall, mendefinisikan konteks sebagai "informasi yang mengelilingi sebuah peristiwa; ia, tidak dapat dipisahkan, menyatu dengan makna peristiwa." Edward Hall menunjukkan bahwa budaya-budaya dunia dan praktik komunikasi individu di dalam budaya merentang dari yang konteks tinggi ke konteks rendah. 
Para pelaku interaksi di dalam budaya konteks tinggi ataupun konteks rendah memiliki beberapa masalah interaksi satu sama lain. Orang- orang dari budaya konteks tiggi, lebih banyak bersandar pada isyarat non- verbal dan apa yang mereka telah ketahui mengenai latar belakang orang, untuk mengarahkan mereka sepanjang percakapan. Sementara orang dari budaya konteks rendah lebih cenderung bertanya secara langsung mengenai pengalaman, sikap, dan keyakinan dari orang lain.

Rasa tanggung jawab terhadap kelompok adalah sebentuk budaya yang dapat dibedakan antara perhatian terhadap kesejahteraan kelompok dan persepsi yang menekankan kepentingan dan hasrat perseorangan. Sederhananya, dalam budaya individualistik, tujuan-tujuan individu adalah kepentingan paling utama, sementara dalam budaya kolektif, tujuan kelompok adalah paling tinggi.

Waktu, sebuah dimensi penting dalam banyak situasi komunikasi, secara khusus penting untuk memahami budaya dan perbedaannya. Hall membedakan dua orientasi waktu: monokronik dan polikronik. Waktu monokronik (monochronic) menjelaskan orientasi orang yang memberi perhatian dan melakukan satu hal dalam satu waktu. Sedangkan waktu polikronik (polychronic) merujuk kepada orang yang memberi perhatian dan melakukan banyak hal dalam satu waktu.

Dalam budaya monokronik, waktu dianggap sebagai komuditas, sebagai sesuatu yang harus dihitung, diatur, dialokasikan, dan dibelanjakan. Waktu monokronik dibagi-bagi secara ketat menjadi pengalaman-pengalaman yang harus terjadwal. Dalam sebuah sistem monokronik, sebuah jadwal atau agenda menjadi amat sangat penting laksana uang, bagaikan sesuatu yang dapat digunakan untuk belanja, ditabung, dibuang, dan hilang.

Sebagian besar karakteristik budaya yang menyelubungi hubungan, kelompok, organisasi, atau masyarakat itu tidak terlihat bagi masing-masing unit ini, sebagaimana udara mengelilingi mereka. Bagi setiap orang, budaya banyak pengaruhnya, sangatlah halus dan meresap serta sering tidak diperhatikan. Padahal, budaya ada dan telah ada karena setiap orang bisa mengingatnya, namun sedikit dari kita yang memiliki alasan untuk merenungkannya.

Karena setiap orang tumbuh dan menggunakan budaya secara apa adanya, maka kebanyakan dari mereka tidak menyadari sifat subjektifnya. Bagi orang yang ada di dalamnya, aspek-aspek budayanya adalah rasional dan sangat bisa dimengerti, namun tidaklah demikian bagi „orang-luar Budaya dan subbudaya tidak hidup dalam ruang hampa. Setiap orang membawa serta pengaruh budayanya pada saat berpartisipasi dalam sejumlah hubungan, kelompok atau organisasi. Saat individu berubah, dia akan menyiapkan dorongan bagi perubahan budaya di mana dia menjadi bagiannya. Dalam pengertian seperti ini, masing-masing kita adalah agen perubahan budaya. 


\section{Budaya Blater}

Blatèr merupakan wajah yang sesungguhnya dari masyarakat Madura, sebelum Madura di "make up" oleh berbagai kultur dominan yang merambahnya. Blatèr sebuah julukan terhadap Masyarakat Madura yang pada intinya adalah sesepuh masyarakat sekitar. Tidak semua orang bisa disebut blatèr, hanya orang-orang tertentu yang bisa dijuluki dengan kata ini. Maka bisa dikatakan juga nama Blatèr adalah sebuah penobatan dari masyarakat di mana belater itu berada. Sebuah penobatan blater tentunya bermacam-macam, ada yang menobati karena kewibawaannya, ada juga karena kabengallah (keberaniannya).

Bagi masyarakat Madura blatèr merupakan salah satu tokoh terpenting selain dari pada pemimpin yang formal maupun nonformal (kyai). ${ }^{9}$ Istilah blatèr hanya popluer di Madura bagian barat (Bangkalan dan Sampang) sedangkan di Madura bagian timur (Sumenep dan Pamekasan) lebih dikenal istilah bajingan, meskipun sebenarnya kedua istilah tersebut tidak sepenuhnya sama. Ada tingkatan dan kelas tersendiri yang membedakan pengertian bajingan dengan blatèr. Potret bajingan lebih kental bermain pada dunia hitam dan memiliki perangai yang kasar dan keras sedangkan blatèr sekalipun dekat dengan kultur kekerasan dan dunia hitam, namun perangai yang dibangun lebih lembut, halus dan memihki keadaban. Di kalangan mereka sendiri dalam mempersepsikan diri, blatèr adalah bajingan yang sudah naik kelas atau naik tingkat sosialnya.

Blatèr atau yang dikenal dengan sosok jagoan yang biasanya memiliki pengaruh ditingkat desa, atau beberapa desa, bahkan hingga kecamatan. Ia memiliki pengaruh karena dianggap dapat menjaga keamanan dan ketentraman lingkungan desa dari gangguan tindak kriminalitas. Sosok blatèr kerap kali dianggap sebagian penduduk desa sebagai "kesatria" lokal yang memiliki jaringan pertemanan yang luas. Untuk menjalin pertemanan yang luas, bahkan sampai lintas kabupaten, blatèr banyak memiliki media untuk merawat komunikasi itu. Remoh, kerapan sapi, sabung ayam, dan sandur adalah media yang tidak saja merajut komunikasi, tetapi juga menjadi ruang bagi kalangan blatèr menakar harga diri, bahkan menaikkan status sosialnya.

Bahkan untuk menunjukkan gengsi kejantanannya, banyak pula kalangan blatèr yang menikahi beberapa perempuan. Melalui remoh itulah pertemuan informal kalangan blatèr dilangsungkan. Kalangan blatèr dapat saling mempertukarkan segala informasi, khususnya raport kriminalitas yang terjadi di daerahnya masing masing. Bagi blatèr yang daerah kekuasaannya minim akan tindak kriminalitas, maka prestisnya dikalangan blatèr lainnya akan meningkat. Sebab dipersepsi blatèr yang bersangkutan benar benar dihormati dan memiliki kewibawaan di mata warganya.

Historisitas atau fenomena sejarah keblatèran dalam banyak hal seringkali

\footnotetext{
${ }^{9}$ AbdurRozaki,MenaburKharismaMenuaiKuasa: KiprahKiaidan Blatersebagai Rezim Kembardi Madura. (Yogyakarta: Pustaka Marwa, 2004). Hal.22-25
} 
merujuk pada sosok jagoan sebagai orang kuat di masyarakat pedesaan. Tak heran bila konstruksi tentang keblatèran sangat terkait pula dengan konstruksi jagoanisme di dalam masyarakat. Blatèr adalah sosok orang kuat di Madura, baik secara fisik maupun magis dan biasanya dikenal memiliki ilmu kebal, pencak silat atau ilmu bela diri. Seorang jago/blatèr dapat dengan mudah mengumpulkan pengikut, anak buah dengan jumlah yang cukup besar. Meskipun besaran jumlah pengikutnya sangat tergantung atas kedigdayaan ilmu (kekerasan) yang dikuasainya. Sosok jago atau blatèr yang sudah malang melintang di dunia kekerasan, dan namanya sudah sangat tersohor karena ilmu kesaktianya akan menambah kharisma dan kekuatannya untuk mempengaruhi banyak orang.

Sekep atau senjata tajam dan kaum blatèr merupakan dua hal yang tidak dapat dipisahkan. Sekep adalah senjata tajam yang biasanya dibawa kemanapun pergi oleh orang Madura terutama kaum blatèr. Banyak jenis sekep yang umumnya mereka bawa, namun yang paling popular dikalang orang Madura adalah clurit. Sekep dalam pengertian umum ialah bentuk senjata yang biasa diselipkan dipinggang sebagai jaminan keselamatan hidup bagi pemakainya. Sekep ini bukan hanya menjadi jaminan di perjalanan. Saat tidur atau saat-saat tertentu sekep juga tidak lepas dari sisi (bagian) pemiliknya. Senjata yang disekep, ada beberapa macam bentuk, biasanya bentuk senjata tajam yang mudah diselipkan dipinggang. Baik berupa pisau, clurit, golok, keris dan atau sejenisnya. Maka tak heran bila suatu ketika berpapasan dengan seseorang Madura, khususnya orang-orang Madura yang hidup di pedesaan, akan tampak tonjolan kecil dibalik baju bagian pinggang. ${ }^{10}$

Celurit bagi kaum blatèr sangat penting artinya baik sebagai sekep maupun sebagai pengkukuhan dirinya sebagai orang jago. Nyekep merupakan kebiasaan yang sulit ditinggalkan oleh kebanyakan laki-laki Madura, khususnya di pedesaan. Pada segala kesempatan mereka tidak lupa untuk membawa senjata tajam terutama ketika sedang mempunyai musuh atau menghadiri acara remo. Cara orang Madura nyekep celurit biasanya berbeda dengan jenis senjata tajam lainnya. Celurit biasanya diselipkan di bagian belakang tubuh (punggung) dengan posisi pegangan berada di atas dengan maksud agar mudah dikeluarkan (digunakan). Senjata tajam sudah dinggap sebagai pelengkap tubuh atau telah menjadi bagian dari tubuh lakilaki madura khususnya kaum blatèr. Hal ini ditunjukkan dengan adanya anggapan dari kaum laki-laki Madura bahwa senjata tajam selalu dibawa kemana-mana untuk melengkapi tulang rusuk laki-laki bagian kiri yang kurang satu.

\section{Metode Penelitian}

Panelitian ini akan menggunakan metode penelitian kualitatif. Penelitian kualitatif bersifat deskriptif, yaitu data yang terkumpul berbentuk kata-kata,

10 Latief Wiyata, Carok: Konflik Kekerasan Dan Harga Diri Orang Madura. (Yogyakarta: PT LKIS, 2002 ). Hal. 67-69 
gambar bukan angka-angka. Kalaupun ada angka-angka sifatnya hanya sebagai penunjang. Data yang di peroleh meliputi transkip interviu, catatan lapangan, foto, dokumen pribadi dan lain-lain. ${ }^{11}$

Untuk jenis penelitian akan menggunakan format deskriptif karena bertujuan untuk menggambarkan, meringkaskan berbagai kondisi, berbagai situasi atau berbagai variabel yang timbul di masyarakat yang menjadi obyek penelitian. Kemudian menarik ke permukaan sebagai suatu ciri atau gambaran tentang kondisi, situasi ataupun variabel tertentu.

\section{Hasil dan Pembahasan}

\section{Eksistensi Budaya Komunikasi Blater Di Desa Tambuko}

Blater yang ada di desa Tambuko ini memiliki dua kategori. pertama, blater yang cendrung melakukan tindakan kriminal dan mengganggu warga di desa mereka sendiri. Ke dua, blater yang cendrung tidak melakukan tindakan kriminal di desa mereka sendiri dan memilih melakukan aksi kriminal di luar lingkungan desa mereka. Dari dua kategori blater di atas, dampak yang akan mereka terima dalam proses komunikasi akan sangat bertolak belakang. Kategori yang pertama akan mengalami kesulitan dalam proses komunikasi dengan masyarakat. Kategori ke dua tidak akan mengalami kesulitan dalam proses komunikasi dengan masyarakat, karena dia tidak memiliki nilai buruk di lingkungan desanya sendiri, meskipun dia menyandang gelar blater yang identik dengan kekerasan dan kriminal.

Di lingkungan desa Tambuko adatistiadat yang disebut tengka sangatlah benar-benar dijaga dalam kehidupan sehari hari. Baik itu warga desa biasa ataupun blater sekalipun haruslah memegang teguh serta menerapkan aturan yang disebut tengka dalam kehidupan mereka. Apabila ada warga yang tidak mengikuti aturan itu, maka mereka akan kehilangan harga diri serta dikucilkan oleh warga desa tersebut.

Tengka adalah suatu adat yang bisa dikatakan seperti layaknya hukum kausalitas. Ketika kamu mendapatkan sesuatu maka kamu harus bisa memberikan sesuatu, dan apabila kamu dilukai maka kamu harus membalas melukai juga. Hal itulah yang ditanamkan oleh para leluhur turun temurun di desa Tambuko tersebut. Dalam dunia blater ada budaya komunikasi yang disebut dengan budaya pangaporah, budaya pangaporah disini bagi seorang blater sangat di perhatikan karena berhubungan dengan keselamatan jiwa mereka. Budaya komunikasi ini berfungsi menghubungkan antara sesame blater, baik itu di dalam desa atau di luar desa dan bahkan bisa sampai di luar Kabupaten sekalipun.

Seorang blater memiliki gaya berpakaian serta aksesoris yang membedakan mereka dengan orang biasa. mereka biasanya menggunakan kopiah yang tingginya di atas rata-rata orang biasa, menggunakan sarung yang dijinjit hampir sampai lutut, memakai jaket kulit hitam, serta selalu membawa sekep, biasanya

\footnotetext{
${ }^{11}$ SudarwanDanim,MenjadiPenelitiKualitatif, (Bandung:CV.PustakaSetia,2002). Hal 51
} 
clurit, guluk atau pisau yang diletakkan di pinggang sebelah kiri dan di kaitkan ke sarung.

\section{Esensi Blater di Desa Tambuko}

Blater yang menyandang banyak sisi negatif di karenakan tindakan mereka yang tidak sejalan dengan masyarakat pada umumnya dan hidupnya yang tidak pernah lepas dengan bau kriminal, juga memiliki nilai-nilai tersendiri di mata masyarakat karena tindakan yang mereka tunjukkan. Wahedi, seorang blater yang dikenal dengan sebutan Mat Celleng yang hidup berdampingan dengan masyarakat desa Tambuko, di nilai sebagai orang yang mempunyai sifat sosial yang tinggi, karena tindakan yang dia lakukan, seperti menjaga keamanan desa dari kasus pencurian atau perampokan meskipun tanpa terstruktur dengan mengggunakan nama besar blater yang di sandangnya.

Apabila seorang blater dapat memberikan keamanan bagi warga desanya maka dia akan mendapatkan nilai tersendiri dari tindakannya itu. Masyarakat akan menilai bahwa blater tersebut betulbetul kuat dan punya pengaruh yang besar dalam dunia kriminal, dan patut untuk dihormati. Dilihat dari segi berpakaian atau busana, maka nilai seorang blater akan terlihat apabila blater itu memakai sarung, jaket, kopiah hitam yang agak tinggi dan membawa sekep. Blater tanpa busana atau pakaian itu maka tidak bisa dikenal sebagai blater, karena hal itu sudah menjadi sebuah nilai serta suatu budaya tersendiri bagi masyarakat desa Tambuko.

Tengka bagi masyarakat desa Tambuko adalah sesuatu yang sangat sensitif dan tidak semua orang dapat melakukannya, apalagi yang berhubungan dengan kekerasan. Blater yang teguh dalam melaksanakan tengka juga dinilai sebagai orang yang memiliki harga diri yang tinggi.

Budaya komunikasi blater yang ada di desa Tambuko lebih banyak yang menggunakan komunikasi yang bersifat simbolik dalam kehidupan sehari-hari ketika berhubungan dengan masyarakat setempat. Hal ini terjadi karena blater tersebut tidak bisa untuk melakukan komunikasi secara langsung dengan masyarakat secara terus-menerus di karenakan waktu yang mereka punya lebih banyak digunakan di luar lingkungan desa mereka sendiri.

Tetapi meskipun begitu, blater yang menjadi subyek penelitian ini memiliki caranya sendiri dalam menjalin hubungan dengan masyarakat dan menunjukkan bahwa dia layak untuk tinggal di lingkungan desa Tambuko dengan cara menjalankan adat-istiadat yang sudah di sepakati oleh masyarakat seperti Tengka serta menggunakan status keblaterannya untuk membantu mengamankan desa.

Bila dikaji secara menyeluruh menggunakan teori komunikasi, proses komunikasi yang digunakan oleh blater yang menjadi subyek penelitian ini menggunakan teori interaksi simbolik dalam proses interaksi yang berlangsung dengan masyarakat desa Tambuko. Karena dengan tindakanlah dia menunjukkan bahwa dia ada dan layak untuk dihormati serta ditakuti. Hal ini menunjukkan bahwa teori interaksi simbolik dapat dijadikan sebagai pisau bedah untuk membedah 
budaya komunikasi blater yang ada di desa Tambuko.

Kajian tentang interaksi simbolik dalam ilmu komunikasi diciptakan oleh Herbert Blumer pada tahun 1937 dan dipopulerkan oleh Blumer juga, meskipun sebenarnya Mead-lah yang paling popular sebagai peletak dasar teori tersebut. Esensi dari teori Interaksi simbolik adalah suatu aktivitas yang merupakan ciri khas manusia, yakni komunikasi atau pertukaran simbol yang diberi makna.

Perspektif interaksionisme simbolik berusaha memahami perilaku manusia dari sudut pandang subyek, perspektif ini menyarankan bahwa perilaku manusia harus dilihat sebagai proses yang memungkinkan manusia membentuk dan mengatur perilaku mereka dengan mempertimbangkan keberadaan orang lain yang menjadi mitra interaksi mereka.

Perilaku atau tindakan yang dilakukan oleh Wahedi yang seorang blater dapat diartikan sebagai sebuah proses komunikasi yang berlangsung secara simbolik karena tindakan atau perilaku yang dia lakukan memberikan arti serta kesan tersendiri bagi masyarakat yang ada di desa Tambuko tanpa harus melakukan komunikasi secara langsung. Karena dengan tindakan yang dia lakukan seperti tetap melaksanakan adat-istiadat yang disebut tengka, dan juga dengan menggunakan simbol-simbol yang menunjukkan bahwa dirinya adalah seorang blater, maka masyarakat akan mengakui dia sebagai seorang blater yang kuat dan patut untuk dihormati tanpa harus dia minta atau mengatakannya.
Dengan adanya proses komunikasi secara simbolik yang secara terus menerus dan berlanjut sampai ke generasi yang selanjutnya maka terciptalah sebuah budaya komunikasi bagi blater yang ada di desa Tambuko. Dengan hanya mengetahui simbol-simbol tersebut, baik itu remaja, paruh baya, dan bahkan orang yang sudah lanjut usia akan mengetahui mana seorang blater dan yang bukan, karena adanya sebuah budaya komunikasi tersendiri yang melekat pada diri seorang blater. Dengan simbol-simbol yang digunakan pada tubuh mereka, maka itu sudah menunjukkan eksistensinya sebagai seorang blater. Seperti dengan gaya berpakaian, aksesoris yang digunakan serta mimik wajah. Dengan menggunakan simbol-simbol tersebut, ketika sedang berpapasan dengan orang lain, maka orang tersebut akan langsung berpendapat bahwa dia adalah seorang blater tanpa harus mengatakan bahwa dirinya adalah seorang blater karena simbol yang terdapat pada tubuhnya, seperti memakai jaket hitam, membawa clurit, kopiah yang tinggi, dan lain-lain.

Sebuah peran sosial yang dimiliki oleh seorang blater juga sangat berpengaruh dalam sebuah proses komunikasi. Dengan memiliki peran yang dapat memukau masyarakat, maka akan mudah untuk diterima serta melakukan sebuah hubungan komunikasi.

Dalam prose penafsiran, Blumer mempunyai dua langkah khas. Pertama, aktor menunjukkan kepada dirinya sendiri benda-benda yang menjadi sasaran tindakannya; dia harus menunjukkan dalam dirinya sendiri benda-benda yang mempunyai makna. Interaksi itu dengan 
dirinya sendiri adalah sesuatu yang lain dari suatu proses yang berkomunikasi dengan dirinya. Kedua, berdasarkan proses berkomunikasi dengan dirinya sendiri tersebut, penafsiran menjadi soal menangani makna-makna. Sang aktor menyeleksi, memeriksa, menangguhkan, mengelompokkan kembali, dan mengubah makna-makna berdasarkan situasi tempat ia berada dan arah tidakannya. ${ }^{12}$

Keterangan Blummer di atas juga sangat terlihat dalam proses komunikasi yang terjadi antara Wahedi yang seorang blater dengan masyarakat desa Tambuko, dengan melalui proses komunikasi dengan dirinya sendiri dan mengerti dengan statusnya yang seorang blater dia akan bisa mengambil tindakan yang tepat dalam melakukan suatu proses komunikasi dengan masyarakat. Karena tanpa dia mengerti dengan keberadaannya dan dirinya sendiri, dia akan kesulitan untuk berbaur dan melakukan hubungan komunikasi yang dapat diterima oleh masyarakat desa Tambuko itu sendiri. Jadi proses pengenalan diri sendiri itu sangatlah penting dalam menentukan tindakan yang akan di lakukan dalam suatu proses komunikasi.

Dengan dapat mengerti serta mengenal dirinya sendiri maka tindakan yang cukup berpengaruh untuk dilakukan dalam proses komunikasi dengan masyarakat desa Tambuko adalah juga dengan memiliki peran sosial yang penting di dalam lingkungan desa Tambuko itu sendiri. Seperti yang dilakukan Wahedi dengan menjadi aparat desa serta menjadi salah satu pengaman desa yang cukup berpengaruh dan dikenal oleh masyarakat dan mempunyai hubungan yang baik dengan kepala desa mesipun bersifat saling membutuhkan. Maka itu sudah menjadi sebuah nilai tersendiri di mata masyarakat desa, dan hal tersebut juga adalah bagian dari sebuah proses komunikasi nonverbal, yaitu dengan memberikan kesan yang baik dan penafsiran yang positif bagi masyarakat desa.

Pengaruh dari sebuah simbol itu sangatlah berperan penting pada persepsi orang yang melihatnya. Karena dengan simbol orang akan memiliki respon yang berbeda beda. Dengan simbol yang digunakan, bisa membuat orang takut, hormat bahkan benci. Jadi harus berhati hati dalam memilih simbol yang akan dikenakan pada tubuh, karena simbol adalah sebuah proses komunikasi yang sedang berlangsung dan terkadang tidak disadari.

Proses komunikasi simbolik ini sangatlah bersifat sensitif karena akan langsung mendapatkan respon dari orang yang melihatnya meskupun belum melakukan komunikasi secara verbal/langsung. Maka harus bisa mengerti seperti apa diri sendiri sebelum melakukan komunkasi yang bersifat simbolik dengan orang lain supaya tidak terjadi kesalah fahaman dalam proses pertukaran informasi yang berlangsung. Karena apabila sampai terjadi kesalah fahaman dalam proses pertukaran informasi maka

${ }^{12}$ George Ritzer, Teori Sosiologi Dari Sosiologi Klasik Sampai Perkembangan Terakhir Postmodern. (Yoyakarta: Pustaka Pelajar,2012). Hal. 627-628 
akan mengalami kesulitan dalam proses komunikasi ke tahap yang selanjutnya dan bahkan bisa berakibat putusnya sebuah hubungan komunikasi itu sendiri.

\section{Kesimpulan}

Proses komunikasi secara non verbal dalam budaya komunikasi blater yang ada di desa Tambuko terlihat dari perilaku, simbol-simbol, dan aksesoris yang digunakan oleh blater tersebut untuk menunjukkan eksistensinya sebagai seorang blater. Perilaku atau tindakan yang dilakukan blater seperti mengamankan desa dan menggunakan tengka/adat dalam kehidupan sehari-harinya sudah menunjukkan sebuah proses komunikasi yang bersifat non verbal. Ditambah lagi dengan simbol, busana, dan aksesoris yang dia kenakan menjadi sebuah budaya komunikasi tersendiri bagi blater yang ada di desa Tambuko. Dengan menggunakan busana serta aksesoris seperti kopiah hitam yang tinggi, memakai jaket kulit, memakai sarung yang agak dijinjit, dan membawa sekep,hal itu sudah menjadi budaya komunikasi tersendiri bagi blater, dan masyarakat akan menyadari bahwa dia adalah seorang blater dengan adanya simbol-simbol serta busana yang dia kenakan pada tubuhnya.

Perilaku, simbol-simbol, dan busana yang ditunjukkan oleh blater menjadi sebuah pesan tersendiri bagi orang yang melihatnya, dan memiliki makna serta nilai-nilai tersendiri bagi masyarakat desa Tambuko. Blater yang mampu mengamankan desa akan dinilai sebagai orang yang mempunyai pengaruh kuat dan ditakuti dalam dunia keblateran. Bagi blater yang tetap mampu menggunakan tengka dalam hidupnya akan dinilai sebagai orang yang mempunyai harga diri yang tinggi.

\section{Daftar Pustaka}

Brant D. Ruben dan Lea P. Stewart. 2013. Komunikasi dan Perilaku Manusia.

Crewell, Jhon W. 2010. Research Design; Pendekatan Kualitatif, Kualitatif, Dan Mixed. Yogyakarta: Pustaka Pelajar.

Danim, Sudarwan. 2002. Menjadi Peneliti Kualitatif. Bandung: CV. Pustaka Setia.

De Jonge, Huub. 1989. Madura Dalam Empat Zaman: Pedagang, Perkembangan Ekonomi, Dan Islam. Jakarta: PT Gramedia.

Departemen Agama RI,. 2004. Al-Qur'an dan Terjemahan: Al Jumanatul' Ali.

Departemen Pendidikan Nasional. 2008. Kamus Besar Bahasa Indonesia, Pusat Bahasa Edisi Keempat. Jakarta: Gramedia Pustaka Utama

Fadlillah. 2003. Menyingkap Mutiara dan Kualitas Hadits. Surabaya: ELKAF.

Jakarta: Rajawali Pers.

Karakteristik Pemimpin Madura, 2013, (www.maduracorner.com/karakte ristik- pemimpin-madura. diakses pada 10 maret 2015).

Kepeminpinan Informal Madura, 2012, (www.lontarmadura.com/kepemi mpinan- informal-madura. Diakses pada 10 maret 2015).

Moleong, j, Lexy. 2006. Metodologi Penelitian Kualitatif. Bandung: PT. Remaja Rosdakarya. 
Muhajir, Noeng. 1996. Metodologi Penelitian Kualitatif. Yogyakarta: PT Bayu Indra Grafika.

Mulyana, Deddy. 2008. Ilmu Komunikasi Suatu Pengantar. Bandung: PT Remaja Rosdakarya.

Mulyana, Deddy. 2008. Metodologi Penelitian Kualitatif: Paradigma Baru Ilmu Komunikasi Dan Ilmu Sosial Lainnya.Bandung: PT Remaja Rosdakarya.

Pemerintahan Vol 2 No1 Februari. Penerbit Arkola.

Ritzer, George.

2012. Teori Sosiologi Dari Sosiologi Klasik Sampai Perkembangan Terakhir Postmodern. Yoyakarta: Pustaka Pelajar.

Sebagai Rezim Kembar di Madura. Yogyakarta: Pustaka Marwa.

Sendjadja, Djuarsa. 1994. Teori Komunikasi. Jakarta: Universitas Terbuka. Raditya, Ardhie. 2011. Politik Keamanan Jagoan Madura. jurnal Studi

Sobur, Alex. 2006. Semiotika Komunikasi. Bandung: PT Remaja Rosda Karya. Pius Partanto dan M. Dahlan Al Barry. 1994. Kamus Ilmiah Populer. Surabaya:

Soehartono, Irwan. 2000. Metodologi Peneiltian Sosial. Bandung: Remaja Rosda Karya

Sugiyono. 2009. Metode Penelitian Kuantitatif, Kualitatif, dan $R \& D$. Bandung: Alfabeta.

Sulaeman, Munandar. 1998 . Ilmu Budaya Dasar. Bandung: PT Refika Aditama. Rozaki, Abdur.
2004. Menabur Kharisma Menuai Kuasa: Kiprah Kiai dan Blater

Wiryoprawiro, Zein. 1986. Arsitektur Tradisional Madura Sumenep. Surabaya : FTSP ITS.

Wiyata,latief. 2002. Carok: Konflik Kekerasan dan Harga Diri Orang Madura. Yogyakarta: PT LKIS. 